\title{
O conceito de civilização e a política indigenista do século XIX
}

\author{
Gabrielly Bononi Miranda *
}

DOI: 10.11606/issn.2318-8855.v9i1p32-54

Resumo: O presente artigo pretende discutir as mudanças ocorridas no Brasil Imperial referentes a política indigenista do século XIX, analisando o conceito de civilização que perpassou todo o contexto imperial, especialmente os últimos anos, e a influência deste conceito na construção desta política no período. Também discutimos a Lei de Terras, promulgada no ano de 1850, apontando para a influência dessa legislação, dita como a novidade do século, na construção da política indigenista e da regulamentação das terras de aldeias e de aldeamentos. Utilizamos o conceito de civilização como referência devido ao Império tratar a necessidade de "civilizar" a nação brasileira em seus aspectos social, político, econômico e cultural, especialmente ao que concernia as populações indígenas, que aparecem quase a todo momento como alvos e objetos de civilização nos documentos oficiais, como os Relatórios de Província referentes ao século XIX, na fonte central, "O Regulamento de Missões de 1845" e na Lei de Terras de 1850.

Palavras-chaves: Civilização, Indígenas, Política Indigenista, Século XIX, Terras

* Graduanda em História pela Universidade Federal de Mato Grosso do Sul, campus de Três Lagoas (UFMS/CPTL); bolsista no Programa de Educação Tutorial (PET) - Conexões de Saberes; bolsista voluntária no Programa Institucional de Iniciação Científica Voluntária (PIVIC) com a pesquisa "A legislação indigenista do século XIX (1831-1889) e os povos originários do Sul de Mato Grosso: sua adesão e implicações" orientada pela Profa. Dra. Maria Celma Borges. 


\section{artigos}

\section{O conceito de civilização e a política indigenista do século XIX}

\section{Introdução}

O século XIX é apresentado por Manuela Carneiro da Cunha (2012, p.56) como um século heterogêneo, possuindo três regimes políticos diferentes: Colônia, Império e República. É nesse período que o Brasil passa de um regime exclusivamente escravista para o convívio com o trabalho assalariado; vivencia um conflito de poderes entre um imperador que abdicou seu mandato e diversos regentes; e um golpe de estado, denominado "golpe da maioridade", que colocou uma criança no poder, chegando até o momento das grandes imigrações livres, a partir dos anos 1870, custeadas principalmente pelo governo Imperial.

Em meio a esse cenário aparentemente caótico, diversas decisões foram tomadas, desde a chegada da família real ao Brasil, no que concernia a transformação da condição de colônia para dar suporte a um Império, como, por exemplo, a criação do Banco Central do Brasil, em 1808; a abertura dos portos para a Inglaterra, entre outras medidas. Afim de compreendermos como se deu esse ideal civilizatório durante o período denominado de Brasil Império, precisamos, primeiramente, compreender no que concernia o conceito de civilização e o que as elites brasileiras buscavam com a ideia de trazer a "civilidade" quando chegaram as terras brasileiras, e que marcaram excepcionalmente os anos finais do século com a conhecida Belle Époque brasileira ${ }^{1}$, abarcando as diversas influências francesas sob a elite e o seu modo de vida, gerando o anseio de transformar um mundo caipira em algo civilizado aos padrões europeus. (DOIN, 2007, p.94).

\footnotetext{
1 Movimento baseado no Impressionismo francês. Foi um período de mudanças na cultura, arte, tecnologia e política no Brasil, durando de 1889 a 1931 (fins do Império e Início da República Velha). Difere da dos outros países pela duração e pelo avanço tecnológico que se deu nas regiões do ciclo da borracha e do café (DOIN, 2007, p.94-95).
} 


\section{artigos}

\section{Gabrielly Bononi Miranda}

Diante desse desejo de transformar a estética das principais capitais brasileiras, em especial a da sede do império, a cidade do Rio de Janeiro, a sociedade brasileira também deveria acompanhar esse avanço, e é por essa razão que o ideário de civilização dos povos indígenas surge com mais ênfase naquele século. Em seu início, o nativo foi colocado como símbolo da nação brasileira, dentro de uma visão romantizada, tido como o "herói da nação", mas personificado aos padrões europeus (FERREIRA JUNIOR, 2015, p.3-4). Entretanto, essa não era a realidade das populações indígenas que existiam nas diversas províncias, tidos como selvagens pela sociedade e pelo governo.

Por conta desse ideal de selvageria é que são criados os projetos de "catequese e civilização" dos nativos, que ocorreriam dentro e fora dos aldeamentos, ao objetivar ensinar aos indígenas a ler, escrever e a contar, bem como ofícios e artes mecânicas. Deveriam ser guiados no trabalho constante e voltado ao comércio, tendo a sua mão de obra orientada, ou mesmo disponibilizada, aos fazendeiros pelos diretores de índios, presentes nos aldeamentos. O trabalho nesse século era tido como um dos itens mais passíveis e o caminho para "civilizar" os indivíduos. E é por meio desse ideal de organização e de civilidade que são criadas diversas leis com o intuito de regulamentar a posse de terras, os aldeamentos, a organização do trabalho desses grupos, entre outras questões.

Nesse sentido, é formulado o "Regulamento de Missões de 1845", apontado por diversos autores, como Manuela Carneiro da Cunha (2012), Patrícia Sampaio (2014), João Pacheco de Oliveira (2006) e outros, como a única legislação propriamente indigenista do século XIX. Esse Regulamento organizava os aldeamentos empregando funcionários que deveriam cuidar e orientar os indígenas dentro dos padrões de civilidade, assimilando-os a sociedade provincial posteriormente. Naquele século, a 


\section{artigos}

\section{O conceito de civilização e a política indigenista do século XIX}

questão de terras se torna um marco importante, especialmente para os nativos que possuíam o direito originário sobre as terras brasileiras. A fim de regulamentar a posse e obtenção de terras de todo o território brasileiro, que agora eram legisladas como mercadorias, bem como o interesse na obtenção de terras de aldeamentos, dáse a promulgação da Lei de Terras de 1850. Ao objetivar compreendermos a Lei em âmbito regional e não apenas nos grandes centros, utilizamos os Relatórios Provinciais, especialmente da Província de Mato Grosso, a fim de compreender como se deu a aplicação desta Legislação nessa região e em outras localidades do império brasileiro.

Desse modo, propomos nesse artigo um estudo acerca do conceito de civilização, importante para o período, em relação aos povos indígenas do Brasil, buscando compreender de qual forma esse conceito influenciou na construção de uma política propriamente indigenista.

Para esta discussão utilizamos como fontes os já citados "Regulamento de Missões de 1845", "Relatórios Provinciais" concernentes ao século XIX e a "Lei de Terras de 1850". Como referenciais teóricos trabalhamos autores, como: Luís Felipe de Alencastro (1997), Maria Odila Leite Silva Dias (1972), João Pacheco de Oliveira (2006), Manuela Carneiro da Cunha (2012), Patrícia Sampaio (2014), Lígia Osório Silva (1997), entre outros autores.

\section{O conceito de civilização no Brasil Imperial}

O oitocentos se inicia de uma forma diferenciada para aqueles que viviam em uma colônia. Portugal passava por uma crise política ${ }^{2}$, contexto em que sua

\footnotetext{
${ }^{2}$ A Europa estava tomada de conflitos com Napoleão Bonaparte, que queria expandir os ideais da Revolução Francesa para o resto do continente, acabando assim com a monarquia. Havia uma grande
} 


\section{artigos}

\section{Gabrielly Bononi Miranda}

população estava sofrendo carências básicas, como consequência da guerra com a França, algo que foi acentuado pelo Tratado de $1810^{3}$ entre Portugal e Grã-Bretanha. Em decorrência dessas circunstâncias, entre outros fatores, internos e externos, tem início o processo de emancipação política do Brasil com Portugal e a consequente vinda da Corte, em 1808, com a ajuda da Inglaterra, sinalizando a construção da sede do reino no Rio de Janeiro, sendo o Brasil colocado como a tábua de salvação para o reino português (DIAS, 1972, p.14-15).

Segundo Alencastro (1997, p.12), em 1808 chegam aproximadamente 15 mil pessoas na colônia, trazendo um grande aparato administrativo, com fidalgos, padres, advogados, praticantes de medicina, funcionários régios e militares. Além dos funcionários reais, muitos setores que eram envolvidos com a monarquia saíram de suas colônias sul-americanas, todas ameaçadas por processos de independência, e se dirigiram para o Rio de Janeiro, em terras da coroa portuguesa, por ser um dos únicos locais que ainda mantinha a monarquia nas Américas. Sendo assim, a cidade carioca se torna a Corte central, sede do comando do Império no Brasil.

O desejo da consolidação de um reino gerou alguns problemas. O principal deles reside no fato de que a colônia não possuía uma estrutura para abarcar tantas pessoas, especialmente acostumadas com um estilo de vida europeu. Laura de Mello e Souza (1986, p.46) enfatiza a dificuldade que os primeiros portugueses a residir aqui tiveram com o clima, e agora a Corte passava pelo mesmo problema. Além disso, o fato de que não havia residências o bastante que acomodassem essas pessoas gerou a expulsão daqueles que moravam nas cidades para outros locais, realocando os

\footnotetext{
desavença com a Inglaterra, então ele instaura o Bloqueio Continental, que consistia em proibir os outros países a fazer comércio com os ingleses, e quem o fizesse seria atacado (HOBSBAWM, 1996).

${ }^{3}$ Chamado de "Tratado de Comércio e Navegação" tinha a finalidade de estreitar as relações entre Portugal e Inglaterra. Estabelecia a redução de impostos de produtos portugueses na Inglaterra e viceversa. (MALERBA, 1999, p.8).
} 


\section{artigos}

\section{O conceito de civilização e a política indigenista do século XIX}

nobres lusitanos em suas casas.

Dias (1972, p.21) salienta que algumas pessoas da elite portuguesa investiram na construção de palácios, de loterias, de propriedades luxuosas, dentre outros tipos de edifícios, além do fato da compra de terras e do estabelecimento de negócios. Percebe-se neste ponto que os lusos já tentavam realizar aproximações entre o novo reino e o mundo conhecido por eles na Europa. A autora ainda ressalta o fato de que acontece um surto de reformas na colônia para reorganizar a metrópole. Nesse ponto, é perceptível a visão de que o Brasil "não era civilizado" e as elites necessitavam realizar esse processo de "civilização", pois grandes construções físicas seriam sinal de uma cidade e sociedade civilizadas.

José Doin (2007, p.92) aponta que o fenômeno do urbanismo, nos meados do XIX, é o responsável por transformar os vilarejos em concentrações de casas, ou seja, em cidades propriamente ditas. O autor ainda destaca o conceito de "modernização conservadora", algo extremamente presente no Brasil Imperial no cenário do século XIX, especialmente a partir dos anos 50, e o qual:

(...) vincula-se ao modo como a costumeira e infeliz manutenção do poder das elites se deu por meio da manipulação do desenvolvimento urbano e do desejo de experimentar os 'novos acessórios modernos (urbanização, telefone e cinema, entre outros). (DOIN, 2007, p.93).

Ou seja, a "modernização" ditada pelas elites no contexto do Brasil Império funcionava como uma forma de tentar manter o poder em suas diversas dimensões, ao passo que se desejava manter a organização monárquica buscando se assemelhar cada vez mais com as formas de cultura, sociedade e estética europeias. Nesse ponto, Doin (2007, p.94) fala sobre a Belle Époque brasileira, movimento em que se tinha um gosto pelo moderno e pela materialidade que envolvia a Europa. O autor ainda apresenta o conceito de modernidade em 3 ângulos, concordando com a visão de 


\section{artigos}

\section{Gabrielly Bononi Miranda}

Marshal Berman: processo histórico de acumulação do capital; projeto de transformação material de costumes e paisagens urbanas; e processos sociais que impulsionaram ou colocaram obstáculos aos investimentos urbanos das elites.

Ao tratarmos do conceito de civilização, concordamos com os dizeres de Vainfas: “(...) o ideal de civilização também foi frequentemente associado ao ideal de progresso, ambos diretamente dependentes da criação da riqueza, da manutenção da produção e da ordem no trabalho (...)" (2002, p.142).

Ainda acerca desse conceito, Ronaldo Vainfas (2002, p.141) realiza uma análise de sua origem europeia, apontando que esse era utilizado muito comumente na França, durante o século XVIII, e possuía um nítido intuito de demarcar um determinado espaço social da nobreza e da burguesia em ascensão. Ao fim do mesmo século, a sociedade francesa também passou a incorporar o desenvolvimento científico, econômico, artístico e tecnológico ao conceito de civilização. O Brasil imperial buscava se enquadrar nesses padrões civilizatórios, no desejo de se parecer cada vez mais com as sociedades europeias, especialmente a França.

Vainfas aponta que nos dicionários franceses do século XVIII "civilidade significava cortesia, urbanidade, polidez, boa educação, boas maneiras, delicadeza, etiqueta, ou seja, era tudo que se opunha a rusticidade grosseira dos setores sociais mais baixos" (2002, p.142). Portanto, a civilização advinha de grandes centros urbanos, com teatros, bancos, restaurantes, museus e grandes exposições de arte.

Aos poucos, pelo Império, especialmente no Sudeste, iam se instalando as mudanças que decorriam da transformação dos pequenos vilarejos em cidades. Como narra Doin, em 1852, o "rei do café" trazia consigo eletricidade, automóvel e telefone, tecidos finos, pavês, bulevares, calçamento nas ruas e os palacetes; o 


\section{artigos}

\section{O conceito de civilização e a política indigenista do século XIX}

aeroporto, teatro e o cinema, entre outras "novidades"; também nesse ano surgiram as primeiras tentativas de realizar a construção de linhas férreas (2007, p. 95). Ou seja, aos poucos a civilidade europeia ia encontrando espaços no Brasil Imperial, especialmente no que concernia às elites.

\section{O conceito de civilização em relação aos povos indígenas}

Associado aos desejos de progresso e de desenvolvimento econômico do país, o conceito de civilização estava vinculado à questão do controle do mundo do trabalho e da religião ${ }^{4}$, especialmente no que concernia aos povos indígenas. Desde o período colonial, a referência ao processo civilizatório dos nativos estava atrelada à catequese e ao ensino destes nos serviços agrícolas e na produção comercial (VAINFAS, 2002, p.142).

Cunha ainda salienta a respeito da questão do trabalho dos indígenas:

(...) numa retórica característica do século XIX, vem expressa em termos pedagógicos: a escravidão temporária dos índios, dobrando-os à agricultura e aos ofícios mecânicos, deveria fazer-Ihes perder sua 'atrocidade' e, sujeitandoos ao trabalho como os sujeitava as leis, elevá-los a uma condição propriamente social, isto é, humana. (CUNHA, 2012, p. 82).

A partir desta citação, podemos notar como no ideário do período o trabalho era entendido como um princípio "pedagógico", visto como algo importante, já que era apresentado como questão "civilizatória e humanista".

Azevedo (1987, p.100) aponta que para os sujeitos do século XIX, especialmente para a elite, o trabalho era o que dava dignidade, liberdade com valor a vida, mais

\footnotetext{
${ }^{4}$ O fim da Idade Média e início da denominada Época Moderna foi marcado por uma religiosidade exacerbada, que caracterizava a civilidade no continente europeu (SOUZA, 1986, p.33).
} 


\section{artigos}

\section{Gabrielly Bononi Miranda}

uma vez reforçando o seu caráter civilizatório.

Cunha ao discutir a questão do trabalho como item civilizatório no contexto do século XIX relata “(...) os índios recém sujeitados recusavam-se ao trabalho (...) eram "mansos", mas ainda não "civilizados" (...)" (2012, p.87). Ou seja, para o olhar dos colonos e da administração imperial, se não desejassem trabalhar conforme os moldes europeus, não poderiam ser compreendidos como civilizados. A amostra de resistência ao trabalho servia para reforçar a imagem de selvagem do indígena em relação ao homem branco do século XIX.

O Regulamento das Missões de 1845 apresenta em seu título “Regulamento acerca das missões de catequese e civilização dos índios", o que as entidades governamentais do período imperial pensavam acerca dos indígenas. Este Regulamento traz em sua composição a recuperação de experiências de outras propostas de "civilização". Sendo assim, além da catequese e do aldeamento, existiam ainda outros interesses e preocupações como, por exemplo, a criação de escolas nas aldeias, incentivo ao desenvolvimento de ofícios e de "artes mecânicas", o estímulo à produção de alimentos visando a subsistência e a comercialização, a atração dos índios errantes e a prática da propriedade coletiva (SAMPAIO, 2014, p.178). Aqueles que fossem civilizados deveriam receber sobrenomes, como em Portugal, como aponta Oliveira (2006, p.72).

O primeiro artigo do Regulamento fala a respeito da função do diretor da aldeia5, que continuava a existir por todo o século XIX mesmo com a extinção do Diretório dos Índios no século anterior. Uma das funções desse diretor era a de

\footnotetext{
${ }^{5}$ Esse cargo foi criado no século XVIII pelo governo pombalino ao instituir o Diretório dos Índios após a expulsão dos jesuítas. Mas, com a dissolução do Diretório, o cargo deveria ser de igualmente forma cancelado, o que não ocorreu (OLIVEIRA, 2006, p.69).
} 


\section{artigos}

\section{O conceito de civilização e a política indigenista do século XIX}

analisar qual a condição da comunidade e dos povos que habitavam os aldeamentos ou regiões onde havia o desejo de implementar aldeamentos.

O primeiro parágrafo do Regulamento diz: “(...) as ocupações habituais dos índios que nelas se conservam; suas inclinações e propensões; seu desenvolvimento industrial; sua população (...); e as causas que tem influenciado em seus progressos ou em sua decadência". Na análise desse trecho podemos notar que já se falava na ideia de "progresso" das aldeias, bem como na ideia de seu "desenvolvimento comercial". O que seria esse desenvolvimento? Nos parece ser a questão do trabalho, pois como aponta o segundo parágrafo, o diretor deve "Indagar os recursos que oferecem para a lavoura, e comercio (...)".

\section{A política indigenista do século XIX e a questão de terras}

A política indigenista do século XIX acompanha as disparidades políticas que apontamos anteriormente devido a heterogeneidade da época. Mas, como sugere Cunha (2012, p.56), a questão indígena nesse período deixa de ser uma questão centralizada na mão de obra para se tornar também uma questão de terras.

Nesse momento, o desejo do Império brasileiro é o de se apoderar das terras de aldeamento, como aponta Cunha (2012, p.56). Na visão da autora, a política do século irá girar em torno da questão de terras, e é justamente essa questão que Sampaio (2014, p.186) aponta como a "novidade do oitocentos" em relação a legislação indígena. Havia agora a possibilidade de aforamento e de arrendamento de terras indígenas. Oliveira (2006, p.74), também salienta esses aspectos, destacando que seria apenas após 12 anos de bom comportamento e contribuição com trabalho que os indígenas poderiam obter terras fora dos aldeamentos, e isso ocorreria por meio da doação. A sugestão e a conveniência de pedidos seriam definidas pelos 


\section{artigos}

\section{Gabrielly Bononi Miranda}

diretores gerais; a eles também caberiam a identificação e a indicação do destino das terras de aldeias que se encontrassem abandonadas.

Antes da conhecida Lei de Terras de 1850, a obtenção destas se fazia por meio do sistema de sesmarias, que perdurou até 1822, em que a preocupação da Coroa era a da utilização produtiva da terra, por isto sua ação consistia em doar um pedaço de terras, a partir da assinatura de uma cláusula que atrelava a posse ao cultivo da terra. O sesmeiro tinha 5 anos para tornar a terra produtiva e se não conseguisse deveria devolver a mesma para o senhor original (SILVA, 1997, p.16). A autora destaca que esse é o sentido original de terras devolutas, terras concedidas que não aproveitadas voltavam ao seu doador. Mas, é preciso observar os limites do sistema de sesmarias e o quanto as suas cláusulas foram burladas no decurso da história colonial do Brasil, como afirma Silva (1997, p.16-17).

Durante o século XIX, o patrimônio público era utilizado em benefício das elites dominantes e o domínio das terras sobre a instância particular ou estatal requeria uma legislação que regulamentasse a estrutura fundiária para o desenvolvimento da economia e construção da nação (PODELESKI, 2009, p.47-48). O governo imperial elabora então a primeira legislação agrária de longo alcance na história do Brasil, que ficou conhecida como Lei de Terras, no ano de 1850. Essa Lei pretendeu impor princípios da política de intervenção territorial, representando uma tentativa do poder público em retomar o domínio sobre as terras devolutas.

Paralelamente ao estabelecimento da Lei de Terras vemos ocorrer o fim do tráfico negreiro, no ano de 1850, algo que gerou uma defasagem no que concernia a mão de obra ${ }^{6}$, propiciando preocupação a elite cafeeira que necessitaria substituir

\footnotetext{
${ }^{6}$ É importante destacar que a Lei Eusébio de Queiroz, que abolia o tráfico negreiro, não gerou um
} 


\section{artigos}

\section{O conceito de civilização e a política indigenista do século XIX}

essa mão de obra escrava pela assalariada, já que a mão de obra escrava estaria limitada ao tráfico interprovincial. Por conta disso, temos um incentivo a partir da segunda metade do século às imigrações advindas principalmente da Europa, algo que dificultou a aquisição de terras aos colonos e também aos trabalhadores nacionais.

Podeleski (2009, p.50) aponta que a venda de terras era um dos meios que o Estado encontrou para custear essa imigração e a colonização que seria realizada, tornando a terra de fato uma mercadoria. Vejamos o artigo $1^{\circ}$ da referida Lei "Ficam prohibidas as acquisições de terras devolutas por outro título que não seja o de compra". Ou seja, a terra só poderia ser obtida por meio da aquisição monetária, não mais pela concessão ou doação.

Além de gerar lucros para o governo, a venda de terras também contribuía para a manutenção da ordem política e para o desenvolvimento da lavoura cafeeira, que crescia cada vez mais a partir da segunda metade do século. Silva (1997, p.17) destaca que a Lei teve demasiada importância em sua posição de delimitar o relacionamento entre o público e o privado, na figura do proprietário de terras, estabelecendo normas. Entretanto, como Podeleski (2009, p.54) e Silva (1997, p.17) salientam, a aplicação da lei e sua interpretação da sofreram diversas limitações por razões, como: a primeira é referente a regulamentação da lei, que deixou a cargo dos ocupantes das terras a iniciativa do processo de sua delimitação e demarcação; em segundo não havia uma proibição expressa da posse; também não deixaram evidente qual seria o valor mínimo cobrado para aquisição da terra. Dentro desse quadro, os

impacto imediato na obtenção da mão de obra, os fazendeiros desejavam fazer a substituição do escravagismo da forma mais lenta possível, mas percebiam a necessidade de criar alguma forma de pagar pela mão de obra assalariada, encontrando na comercialização da terra esse meio (CAVALCANTE, 2005, p.4). 


\section{artigos}

\section{Gabrielly Bononi Miranda}

pequenos posseiros argumentaram legalmente sobre sua produção de cultura em determinada terra que poderia fazê-lo proprietário, mas a Lei quase sempre favoreceu ao grande posseiro, mostrando a sua face, ao não reconhecer os pequenos posseiros, como demonstra o artigo 6:

Art. $6^{\circ}$ Não se haverá por principio de cultura para a revalidação das sesmarias ou outras concessões do Governo, nem para a legitimação de qualquer posse, os simples roçados, derribadas ou queimas de mattos ou campos, levantamentos de ranchos e outros actos de semelhante natureza, não sendo acompanhados da cultura effectiva e morada habitual exigidas no artigo antecedente (Art. 6 da Lei $n^{\circ} 601$ de 18 de setembro de 1850).

Importante salientar que havia ressalvas na Lei na questão da concessão de terras para os indígenas, ficando algumas áreas permitidas para a colonização dos indígenas, vide o artigo 12. “O Governo reservará das terras devolutas as que julgar necessarias: $1^{\circ}$, para a colonisação dos indígena (...)". Ou seja, para a criação dos aldeamentos e para fundamentação das aldeias, as terras já ocupadas por indígenas continuariam assim e as regiões que necessitassem da constituição de aldeamentos para "civilizar e catequisar" os nativos receberiam terras para esses fins. Como Cunha aponta, prioritariamente, ou ao menos na Lei, os indígenas teriam o direito às áreas ocupadas, mas parece não ter sido isto o que aconteceu, como salienta a Câmara da vila de Barbacena: "deve ser a arbítrio e escolha dos mesmos índios: parece injustiça que ao dono da casa se determine o lugar para sua estada" (apud CUNHA, 2012, p.71).

A própria Lei de Terras de 1850 esclarece que o direito dos povos indígenas às terras é um direito originário ${ }^{7}$. Ou seja, aparentemente e "juridicamente" ninguém poderia se apropriar das terras de aldeamento. Entretanto, com o desejo da

\footnotetext{
${ }^{7}$ Antecede ao próprio Estado (CÂMARA DA VILA DE BARBACENA, apud. CUNHA, 2012, p. 71).
} 


\section{artigos}

\section{O conceito de civilização e a política indigenista do século XIX}

comercialização e utilização das terras férteis, o cenário muda. Houve diversas alegações por parte dos grandes fazendeiros acerca do desapego dos nativos com as terras devido ao nomadismo e o fato de que já não haviam mais indígenas em aldeamentos, alegando a integração e/ou assimilação dos mesmos na sociedade, e esses locais, passaram a ser comercializados (CUNHA, 2012, p.80).

Nos Relatórios Provinciais de Mato Grosso, como o do ano de 1879, por exemplo, era afirmada a necessidade do aldeamento para conter as "hordas selvagens". Os indígenas eram vistos assim por realizarem "atentados" para com os moradores das províncias, como o caso dos índios Coroados, da região do rio São Lourenço. Para os fins do aldeamento eram dadas pelo governo áreas inutilizáveis, pois, na visão imperial, as terras boas deveriam ser dadas aos agricultores e comerciantes, já que dessa forma teriam algum retorno econômico. Na perspectiva do governo imperial, os nativos eram vistos como imprestáveis, apenas usufruiriam de terras boas para a subsistência, sem oferecer ao Império um retorno monetário.

Outra característica forte do período é a discussão que se dá a respeito de uma política propriamente indigenista, pois anteriormente, no contexto da colônia, os indígenas, em reduções, encontravam algum apoio para a permanência em suas terras a partir da obra jesuítica. Após as reformas pombalinas e a expulsão dos jesuítas da colônia, o Diretório dos Índios passa a ser este instrumento de "defesa" dos indígenas aldeados, mas ao ser revogado em 1798, deixa esses sujeitos sem um respaldo legislativo, especialmente no que concernia a posse de terras.

No século XIX diversas questões são levantadas a respeito dos povos originários até chegar a culminar no Regulamento das Missões, em 1845. Uma das primeiras questões que Cunha $(2012$, p.58) pontua é a da "humanidade dos índios". A 


\section{artigos}

Gabrielly Bononi Miranda

autora diz que é neste período, devido ao cientificismo encontrado no século pelas influências iluministas, que a questão de que se os povos originários "são humanos?" é levantada novamente. Ressalta a autora que no âmbito nacional a humanidade dos indígenas seria afirmada, mas no nível interno do país, eles eram vistos como "selvagens", ou até mesmo como "bestas". Isso se dá devido a uma visão romântica existente nas áreas centrais do Império acerca do "bom selvagem", podendo ser exemplificada pelas obras de José de Alencar. Entretanto, como observa Ferreira Junior (2015, p.3-4), no interior das províncias os moradores estavam em contato com o "índio real" e esse era tido como "selvagem" por não atender aos padrões romantizados.

Outra questão que Cunha destaca é a classificação dos povos indígenas entre "bravos" ou "mansos/domésticos". A primeira categoria diz respeito aos grupos que são encontrados guerreando nas fronteiras do Império. Nesses grupos, afirma poderem ser interpretados os povos Botocudos, sendo aqueles que acabaram entrando em guerra com D. João VI para a liberação da colonização do rio Doce (ES). Isso ocorrera porque o rei era adepto da violência para abrir os caminhos que desejava. Ele reabre as chamadas "Guerras Justas"8. Na segunda categoria, são colocados aqueles que estão "domesticados" em aldeamentos, sedentarizados, “adeptos ao jugo suave das leis" (CUNHA, 2012, p.61).

\subsection{O Regulamento das Missões de 1845}

O Regulamento é apresentado por Cunha (2012, p.68) como a única legislação

\footnotetext{
${ }^{8}$ Conflitos autorizados pela Coroa portuguesa quando os indígenas se recusavam a conversão a fé católica, ou impediam a divulgação da religião. Também ocorria quando os colonos necessitavam de escravos. Diversas vezes os colonos utilizavam esse pretexto, alegando serem atacados pelos índios para conseguir terra ou escravos, como foi citado anteriormente (CUNHA, 2012, p.63).
} 


\section{artigos}

\section{O conceito de civilização e a política indigenista do século XIX}

propriamente indigenista do século XIX. Sampaio (2014, p.178) salienta que é com este documento que se tentará estabelecer as diretrizes mais sérias, mais administrativas do que políticas, para o governo dos índios aldeados. A legislação criou uma estrutura de aldeamentos, com um diretor geral e um diretor geral de índios, tesoureiro, médico e diversos outros funcionários para contribuir nessa tentativa de ordenamento das aldeias.

O Regulamento designa pontualmente quais os cargos administrativos e suas respectivas funções, sendo uma delas a de Missionário. Após a saída de Pombal, a Igreja Católica retoma os trabalhos de "catequese e civilização" dos indígenas nos aldeamentos, com o convite aos missionários capuchinhos, no ano de 1840, advindo do regente Araújo Lima. Algumas das funções do missionário seriam:

Art. $6^{\circ}$ Haverá um Missionario nas Aldêas novamente creadas, e nas que se acharem estabelecidas em lugares remotos, ou onde conste que andão Indios errantes. Compete-Ihe:

$\S 1^{\circ}$ Instruir aos Indios nas maximas da Religião Catholica, e ensinar-Ihes a Doutrina Christã.

$\S 3^{\circ}$ Fazer o arrolamento de todos os Indios pertencentes á Aldêa, e seu districto, com declaração dos que morão nas Aldêas, e fóra dellas; dos baptisados, idades e profissões; e dos nascimentos, e obitos, e casamentos: para o que lhe serão fornecidos os livros pelo Bispo Diocesano, pela caixa das Obras Pias.

$\S 5^{\circ}$ Representar ao Director Geral, por intermedio do da Aldêa, a necessidade que possa haver de outro Missionario, que o ajude, principalmente se houver nas vizinhanças Indios errantes, que seja mister chamar á Religião e sociedade. $\S 6^{\circ}$ Ensinar a ler, escrever e contar aos meninos, e ainda aos adultos, que sem violencia se dispuzerem a adquirir essa instrucção. (Art. $6^{\circ}$ do decreto $n^{\circ} 426$, de 24 de julho de 1845).

Conforme podemos perceber, ao missionário compete agora mais do que apenas ensinar a religião, estabelecer também o projeto de escolas dentro dos aldeamentos, a fim de ensinar as letras e os números, além de ofícios como marcenaria, aos meninos e costura as meninas (SAMPAIO, 2014, p.198). A inserção 


\section{artigos}

\section{Gabrielly Bononi Miranda}

dessas outras atividades provinha do ideário civilizatório dos capuchinhos de combinar o ensino religioso com o de artes mecânicas (OLIVEIRA, 2006, p.82). Além disso, deveriam atrair os ditos "índios errantes", que viviam fora desses aldeamentos, vivendo conforme seus costumes, para a civilidade.

Os outros funcionários deveriam cuidar da vida cotidiana, incentivando o cultivo de alimentos, monitorando contratos de trabalho, mantendo a tranquilidade e o policiamento nas aldeias, regulando acesso de comerciantes, trazendo índios não aldeados, controlando as terras dos indígenas, entre outras tarefas (SAMPAIO, 2014, p.190).

Sampaio (2014, p.186) faz um levantamento importante do Regulamento das Missões, apresentando pontualmente o que cada artigo designa. Conforme a autora: os artigos $1^{\circ}$ e $2^{\circ}$ tratam a respeito do diretório geral e dos diretores de aldeias; os artigos, $3^{\circ}, 4^{\circ}, 5^{\circ}, 6^{\circ}, 7^{\circ}, 8^{\circ}$ e $9^{\circ}$ tratam a respeito dos funcionários do aldeamento e dos procedimentos administrativos; 0 artigo $6^{\circ}$ é relativo ao trabalho dos missionários; o $10^{\circ}$ e o $11^{\circ}$ tratam das condições de substituição dos cargos e das graduações recebidas em remuneração aos serviços. Analisando o conteúdo de cada artigo, notamos uma preocupação do Império em administrar as aldeias de "forma correta", como se fosse uma espécie de negócio ou até mesmo uma espécie de cidade dentro da província, com a necessidade de um tesoureiro, um médico, um diretor que deveria cuidar de tudo, inclusive do processo de ensinar o índio ao trabalho e assim levá-lo a "civilidade". A autora ainda aponta que o Regulamento foi um desastre para os povos indígenas, reforçando o processo de expropriação de suas terras (SAMPAIO, 2014, p.187).

A função mais importante apontada nesta Legislação é a do diretor geral de 


\section{artigos}

\section{O conceito de civilização e a política indigenista do século XIX}

índios, que possuía atribuições referentes a organizar e controlar aquela determinada comunidade. Este cargo designaria todos os outros, ou seja, quem seriam os diretores de aldeia, tesoureiro, médico e almoxarife; também era o diretor geral quem indicava ao presidente da província quais as terras do aldeamento ${ }^{9}$.

§ 11. Propôr ao Presidente da Provincia a demarcação, que devem ter os districtos das Aldêas, e fazer demarcaras terras que, na fórma do § 15 deste artigo e do $\S 2^{\circ}$, forem dadas aos Indios. Se a Aldêa já estiver estabelecida, e existir em lugar povoado, o districto não se estenderá além dos limites das terras originariamente concedidas á mesma

§ 33. Propôr ao Presidente da Provincia o Director da Aldêa, o Thesoureiro, Almoxarife e o Cirurgião, preferindo-se para estes empregos os casados aos solteiros; suspender os tres ultimos, e em geral a todos os que estão empregados no serviço das Aldêas, nomeando interinamente quem os substitua, e dando parte immediatamente ao Presidente, ou ao Director da Aldêa, segundo pertencer a nomeação ao primeiro, ou ao segundo (Art. $1^{\circ}$ do decreto $n^{\circ} 426$, de 24 de julho de 1845).

Esse cargo de diretor geral dos índios decidia o que havia de importância em relação aos povos indígenas; se deveriam ter terras, se não deveriam e apontavam ainda pessoas para cuidar da segurança e dos recursos financeiros.

Ao analisarmos a Província de Mato Grosso encontramos a seguinte situação. No Relatório Provincial do ano de 1851, o presidente Augusto Lerverger relata:

Quasi nenhuma applicação se tem feito das disposições do Regulamento n. 426 de 24 de julho de 1845, e muitas dellas parecem me inexequíveis, pelo menos, na actualidade; mórmente pela carência de pessoal idôneo para administração das aldêas na forma do dito Regulamento (...) (LERVERGER, 1852, p. 43).

\footnotetext{
${ }^{9}$ Estas seriam dadas aos índios que apresentassem bom comportamento; seriam terras coletivas e passíveis de arrendamento.
} 


\section{artigos}

\section{Gabrielly Bononi Miranda}

Como podemos notar pelo relato do dito presidente, a existência de uma Legislação não propriamente funcionou em todas as províncias. É possível perceber que a província mato-grossense não estava fazendo aplicação do Regulamento devido à falta de pessoas para viverem nos aldeamentos e para administrá-los, fora a questão monetária que se apresentou como um problema em alguns relatórios nos últimos anos do império.

Sampaio (2014, p.197) diz que o Regulamento já nasce sob o signo de reforma. Havia uma crítica à autonomia dos missionários, bem como o apontamento da escassez destes. A carência de missionários citada pela autora é relatada nos Relatórios Provinciais de Mato Grosso a partir do ano de 1857. Houve também denúncias de abusos dos diretores para com os índios e por essas razões foi apontada a necessidade de uma reforma. Nesta situação, é indicado pelo imperador e presidentes de província que os missionários assumam os cargos de diretores de aldeamento. Pressupomos que por já estarem trabalhando com esses povos há muito mais tempo.

Com a criação do Ministério da Agricultura, a administração e indicação dos diretores ficaram a cargo desta pasta, apontando para a necessidade de realização de reformas. Mas, conforme Sampaio, não é realizada nenhuma grande mudança no sentido da "catequese e civilização" dos indígenas, mantendo as mesmas prerrogativas, quais sejam: atração dos índios ao processo de "civilização" cuidado com a "catequese e educação", esforço de estimular a produção interna e de assegurar a auto sustentação do aldeamento (SAMPAIO, 2014, p.195).

Por meio do Regulamento vemos justamente a tentativa da administração imperial de impor uma dita "civilidade" aos indígenas conforme os padrões europeus, 


\section{artigos}

\section{O conceito de civilização e a política indigenista do século XIX}

estabelecendo líderes religiosos e governamentais que os ensinassem o trabalho diário para capacitá-los à comercialização, aos ofícios, ao letramento e a língua portuguesa, entre diversos outros interesses que caracterizavam o que era "civilização" para os colonos.

\section{Considerações finais}

A partir dessa reflexão histórica do contexto imperial, em que trabalhamos o conceito de civilização, a política indigenista e a questão de terras durante o século XIX, podemos perceber todo um caminho de construção da nação brasileira em padrões que demonstrassem a "civilidade", extinguindo e modificando tudo aquilo que não atendesse a esses padrões, que eram demasiadamente inspirados nas sociedades europeias.

Enquadrados entre o extermínio e a mudança de hábitos, de práticas e de valores, estão os povos indígenas, que em um primeiro momento do século são colocados como a personificação da nação brasileira, especialmente os da etnia TupiGuarani, tidos como o "bom selvagem", ilustrados nas obras de José de Alencar, como "Iracema" e "O Guarani", bem como nas obras de outros autores da época.

Ainda naquele século também passaram a serem ilustrados como "selvagens, bestas, primitivos", o que Ferreira Junior (2015, p.5) chama de o "índio real", e diversas localidades, como a região do Mato Grosso, estavam em contato com esse indígena real, que praticava insurreições elencadas como a barbárie, a exemplo do roubo de gado e de bens materiais, do incêndio de propriedades e de plantações, do assassinato de fazendeiros, do afugentamento de viajantes pelas estradas, dentre outros ocorridos, como formas de resistir ao processo de ocupação de suas terras e de reagir às tentativas civilizatórias por parte das sociedades coloniais ao seu 


\section{artigos}

\section{Gabrielly Bononi Miranda}

entorno. Até mesmo dentro dos próprios aldeamentos ocorriam resistências para com a arbitrariedade praticada pelos missionários ou diretores provinciais, como aponta Oliveira (2006, p.78). Este autor salienta que diversas populações indígenas, em diferentes províncias, mantinham seus ritos tradicionais e passaram a utilizar também de meios legais para demonstrar sua insatisfação para com a forma de tratamento dentro dos aldeamentos. Questão que Cunha (2012, p.94) exemplifica com atos de resistência, praticados em 1815, pelos índios Aramaris na Bahia; outro em 1825 por um indígena da etnia Xakuru, ao prestar queixa contra os abusos ocorridos pelo diretor geral de índios; entre outras ações ao longo do Império.

Partindo dos ideais europeus em regulamentar a administração do Império, são criadas diversas leis e decretos com esse fim. Trabalhamos no artigo o Regulamento de Missões, promulgado em 1845, entendendo-o como uma legislação propriamente indigenista. Entretanto, Moreira (2010, p.56) destaca que a busca pela criação de uma legislação propriamente indigenista era uma questão estratégica, que se justificava por ideais "humanitários e filantrópicos". Mas, o Império via essas diferentes populações apenas como mão de obra mal administrada e pouco aproveitada. Portanto, o Regulamento nada mais era do que um mecanismo de tentativa de controle e ação de colonização efetiva por parte dos colonos para com as populações indígenas, já que dentro dos aldeamentos eles seriam obrigados a aprender a língua da nação, ou seja, o português; também a exercer o "ofício", o trabalho, conforme os padrões europeus e as diversas outras atividades concernentes ao mundo do colonizador.

Da mesma forma funcionava a Lei de Terras de 1850 em relação às terras indígenas e às de aldeamento. Era um mecanismo estatal para regulamentar as posses do Império, numa tentativa de separar o público e o privado, garantindo, em 


\section{artigos}

\section{O conceito de civilização e a política indigenista do século XIX}

certo sentido, o direito originário dos povos nativos. Entretanto, diferentemente disso, funcionou como mais um mecanismo de expropriação e venda das terras indígenas e de aldeamentos, pois os fazendeiros ou dizimavam as populações das terras que eram desejadas ou alegavam que pela assimilação dos nativos com as sociedades provinciais não havia mais índios naquelas localidades, dispensando a necessidade de resguardar terras para aldeamentos. Tais ações faziam com que os nativos reagissem de inúmeras formas, a exemplo da violência, a fim de impedir a tomada de suas terras, e ao mesmo tempo resistir ao avanço das vilas e cidades para dentro de suas aldeias. Também a instalação de fazendas de café, outras grandes lavouras e a pecuária, por exemplo, nas terras indígenas, fazia com que reagissem no modo possível de cada dia.

É importante destacarmos que, ao se interpretar a história indígena, desde a colônia, é comum o que John M. Monteiro (2001, p.4) denomina de "a crônica da extinção", sendo apresentada como um resumo da história indígena, limitada aos processos de dizimação e extinção. Mas, como sugere este autor, diversas formas de resistência foram praticadas, vividas, em todo o território, desde a Colônia e Império, nas diferentes localidades em que se encontraram e de diferentes formas.

Ao compreendermos as legislações que se deram antes da Primeira República, podemos entender os caminhos e as cruzadas das lutas dos povos indígenas e do Movimento Indígena nos séculos XX e XXI, as quais continuam, e se fortalecem neste século, seja na luta pela demarcação de terras e/ou ainda pelo reconhecimento e pela validação de suas identidades. Reivindica-se também a escrita de uma história que faça jus às suas diversas realidades e não apenas resuma os povos indígenas ao primitivismo e extermínio. 


\section{artigos}

Gabrielly Bononi Miranda

Referências Bibliográficas:

ALENCASTRO, Luiz F. de. Vida privada e ordem privada no Império. In.: SOUZA, Laura de M. e. ALENCASTRO, Luiz F. de. (Org.) História da vida privada do Brasil, v. 2. São Paulo: Cia das Letras, 1997.

AZEVEDO, Célia Maria de. Onda negra, medo branco; o negro no imaginário das elites - século XIX. Rio de Janeiro: Paz e Terra, 1987.

CAVALCANTE, José Luiz. A Lei de Terras de $\mathbf{1 8 5 0}$ e a reafirmação do poder básico do Estado sobre a terra. São Paulo: Revista Histórica, 2005.

CUNHA, Manuela Carneiro da. A política indigenista no século XIX. In: índios no Brasil: história, direitos e cidadania. São Paulo: Claro Enigma, 2012, p. 56-95.

DECRETO No. 426 - DE 24 DE JULHO DE 1845 - disponível em: http://hernehunter.blogspot.com/2013/12/regulamento-das-missoes-1845.html último acesso em: 21/05/2020 às 20:33.

DIAS, Maria Odila Leite da Silva. A interiorização da metrópole, In: MOTA, Carlos Guilherme (org.). 1822 - Dimensões. São Paulo, Perspectiva, 1972.

DOIN, José Evaldo de Mello. A Belle Époque caipira: problematizações e oportunidades interpretativas da modernidade e urbanização no mundo do café (1852-1930). São Paulo, Revista Brasileira de História, 2007, v.27, n55.

FERREIRA JUNIOR Adalto Vieira. Brandura e violência: a política indigenista em Mato Grosso nos relatórios dos presidentes de província (1830-1886). XXVIII Simpósio Nacional de História, Florianópolis - SC, 2015.

HOBSBAWM, Eric. A Revolução Francesa. In: HOBSBAWM, Eric. A Era das Revoluções. São Paulo: Paz e terra, 1996.

LEI No 601, DE 18 DE SETEMBRO DE 1850 - disponível em: http://www.planalto.gov.br/ccivil_03/LEIS/L0601-1850.htm último acesso em: 21/05/2020 às 20:38.

MALERBA, Jurandir. O Brasil Imperial (1808-1889): panorama da história do Brasil no século XIX. Maringá: Eduem, 1999.

MONTEIRO, John M. Tupis, Tapuias e Historiadores: estudos de História Indígena e do Indigenismo. Campinas: IFHC-UNICAMP, agosto de 2001. 
O conceito de civilização e a política indigenista do século XIX

MOREIRA, Vânia. 0 ofício do historiador e os índios: sobre uma querela no Império. São Paulo: Revista Brasileira de História, v. 30, n 59, p. 53-72, 2010.

OLIVEIRA, João Pacheco de. A presença indígena na formação do Brasil. Brasília: MEC/UNESCO, 2006.

PODELESKI, Onete da Silva. Lei de terras de 1850. Florianópolis: Revista Santa Catarina em História - UFSC, v.1, n.2, 2009.

RELATÓRIO apresentado pelo presidente Augusto Leverger, na abertura da sessão ordinária da Assembleia Legislativa Provincial em 10 de maio de 1851.

RELATÓRIO apresentado pelo presidente João José Pedrosa, abriu a $2^{\circ}$ da $22^{a}$ legislatura da respectiva Assembleia em 1 de outubro de 1879.

SAMPAIO, Patrícia Melo. Política indigenista no Brasil imperial. In: GRINBERG, Keila e SALLES, Ricardo (org.) O Brasil Imperial. Vol. 1, Rio de Janeiro: Civilização Brasileira, 2014.

SILVA, Lígia Osório. As leis agrárias e o latifúndio improdutivo. São Paulo em Perspectiva, 1997.

SOUZA, Laura de Mello e. $\mathbf{O}$ diabo e a terra de Santa cruz: feitiçaria e religiosidade popular no Brasil colonial. São Paulo: Companhia das Letras, 1986, pp. 21-85.

VAINFAS, Ronaldo. O dicionário do Brasil Imperial (1822-1889). Rio de Janeiro: Objetiva, 2002. 